\title{
ORAL SANDER'İ UĞURLARKEN
}

\author{
Prof. Dr. Ömer KüRKÇÜOĞLU*
}

Oral Ağabcy'le aynı ortaokul, lise ve fakültceden dört yıl arayla mezun olduk. 1964'te O, 1968'de ben, Fakültemiz' in Siyasi Tarih Kürsüsü'ne Asistan olduğumuzda Dış Münasebetler Enstitümüz çok ünlü isimlerden oluşan, kalabalık bir kadroya sahipti. Bu Hocalarımızın büyük kısmı 8-9 yıllık kısa bir süre içinde başka devlct görevlerine geçme, emeklilik ve vefat nedenleriyle aramızdan ayrıldılar. Bu durum, Bölüm'ün genç elemanlarının çok crken tarihlerde sorumluluk mevkilerine gelmelerini gercktirdi. Oral Ağabey de Asistanlığa atanmasından 12 yıl sonra Kürsü (Anabilim Dahı) Başkanı olmuştu. O surada 1 yıllık Doçcnt'ti.

Oral Ağabey bu görevini de başarıyla yürüttü.

Oral Ağabcy'in Siyasi Tarih alanına en büyük katkısı, konuyu çok geniş bir çerçevede ele almasıdır. Diplomat için "her şeyden anlayan kişi" tanımı da yapılır. Oral Ağabey de Diplomatik Tarih'i (Siyasi Tarih'i) çok-yönlü, disiplinlerarası bir çerçevede ele almışır. Siyasi Tarih'i bir Uygarlık Tarihi, Kültür Tarihi temeline oturtmuştur.

Elbctte böyle yapabilmiştir. Çünkü kendisi de çok-yönlüydü. Geniş bir kültür birikimine sahipti. Gerçek bir aydındı.

Hem kurallara saygılı, disiplinli, hem de gerek kendișine, gerek başkalarına karşı son derece özgürlükçüydü. Disiplin ve özgürlükçüllük kavramlarının birarada yaşayabileceğine en iyi bir örnckti.

Oral Ağabey'in çok-rcnkli bir kişiliği vardı. Enerjik, çalışkan, yenilikçi, dę̧işik bir insandı. Yaşından çok daha genç görünürdü. Bunun temcl nedeni $f_{2}^{\prime}$ 'ren genç oluşuydu. Her yaştan gençlerle diyalogu mükemmeldi.

Girdiği her toplulukta yıldızlaşırdı.

O'nunla fikir tartışması yapmak da ayrı bir güzcllikti. Sportmen ruhluydu.

*A.U. Siyasal Bilgiler Fakültesi Ögretim Üyesi 
Kendisine yapılan bazı şakalara haklı olarak kızdığı görülürdü. O pek şaka yapmazdı.

Ama bu defa $\mathrm{O}$ hepimize çok acı bir şaka yapu. Yerinde duramayan, ama gittigi yerlerden bir gün tekrar dönen Oral Ağabey, bu defa dönüşü olmayan yere gitti. Kendisine belki de en çok muhtaç olduğumuz, en verimli olabileceği bir dönemde bizleri boynu bükük, kolu kanadı kırı halde buraktı.

Oral Ağabey, varlığında olduğu gibi, yokluğunda da hep bizimle yaşayacaksın.

Nur içinde yat. 